\title{
Bank risk behavior and connectedness in EMU countries
}

\author{
Manish K. Singh ${ }^{\mathrm{a}}$, Marta Gómez-Puig ${ }^{\mathrm{b}}$, Simón Sosvilla-Rivero ${ }^{\mathrm{c}, *}$ \\ ${ }^{a}$ Department of Economic Theory, University of Barcelona, Spain. \\ E-mail address: manish.singh@barcelonagse.eu \\ ${ }^{b}$ Department of Economic Theory, University of Barcelona, Spain. \\ E-mail address: marta.gomezpuig@ub.edu \\ ${ }^{c}$ Complutense Institute of International Economics, Universidad Complutense de \\ Madrid, Spain. E-mail address: sosvilla@ccee.ucm.es
}

\begin{abstract}
Given the structural differences in banking sector and financial regulation at country level in European Economic and Monetary Union (EMU), this paper tries to estimate the banking sector risk behavior at country level. Based on contingent claim literature, it computes "Distance-to-default (DtD)" at bank level and analyses the aggregate series at country level for a representative set of banks over the period 2004-Q4 to 2013-Q2. The indices provide an intuitive, forward-looking and timely risk measure having strong correlations with national/regional market sentiment indicators. An underlying trend exists but causality tests suggest no systemic component. Cross-sectional differences in DtD suggests fragility in EMU countries 12-18 months prior to the crisis and better predictive ability than the regulatory index based on large and complex banking institutions at European level. Furthermore, we explore the reasons for this divergence using VAR estimates.
\end{abstract}

Keywords: contingent claim analysis, Distance-to-default, banking risk JEL: G01, G13, G21, G28

\section{Introduction}

The 2007-08 financial crisis and the subsequent European sovereign debt crisis have exacerbated the need to understand and monitor the bank risk behavior. Renewed attention is being focused at the global scale to enhance

${ }^{*}$ Corresponding author. Tel: +34 913942342; Fax: +34 913942591. 
and extend risk measurement methodologies. The eurozone is no exception and the twin objective of the European Central Bank (ECB) - price and financial system stability - places a strong emphasis on Systemically Important Financial Institutions (SIFI) but relies on individual countries' central banks to supervise smaller financial institutions.

This paper deviates from this current and in our view excessive focus and attention on detecting and monitoring risk at European banking level. We take a step backward and introduce a micro approach to document and monitor the buildup of banking sector risk at country level. Based on contingent claims literature, we calculate "Distance-to-default (DtD)" at bank level and analyze the aggregate series at country level for a representative set of banks over the period 2004-Q4 to 2013-Q2. Conceivably, if regulators pay greater attention to country-specific buildups of risk and their connectedness, they might take actions earlier to mitigate the extent and impact of future crisis.

There are many reasons for this choice. First, the structure of the banking sector within EMU countries varies considerably. In the case of Germany, Finland and the Netherlands, total banking sector assets are relatively concentrated, while in Italy, Greece, France and Austria, they are distributed quite equitably. Figure 1 summarizes this information by plotting the relative size of banking firms (by total assets in 2010) in individual EMU countries, where the total asset of the biggest bank in a particular country is normalized to one. Excessive asset concentration lowers regulatory cost but makes countries vulnerable to the actions of individual institutions.

[Figure 1 about here.]

Second, countries economic dependence on the banking sector varies drastically. ${ }^{1}$ Consider the case of Luxembourg, where the total financial assets under management is roughly 25 times the Gross Domestic Product (GDP) at current prices while, in Greece, Italy and Finland, this multiple is less than three (Figure 2a). In some countries, all financial services are provided by banks, while in others there are specialized mortgage, pension and insurance companies. Given the existence of deposit insurance at the national level, governments implicitly or explicitly guarantee bank deposits; which in

\footnotetext{
${ }^{1}$ We consider total asset managed by banking firms as a proxy for relative economic dependence.
} 
times of stress, can transfer huge contingent liabilities onto sovereign's balance sheets and bailing out may lead to the weakening of government's own position.

[Figure 2 about here.]

Third, the excessive home bias in European banks' asset portfolios (Figure $2 \mathrm{~b}$ ) creates a vicious circle for risk transfer between banks and sovereigns, which creates perverse economic and political incentives for government to save domestic banks. The existence of financial regulation at national level provides governments with the means to pursue their own national interests. Also noteworthy is the home bias in the private investors portfolio (Belke and Schneider (2013)) which aggravates this problem further. Neighborhood effects, close connectedness with certain countries and cross country differences in bailout strategy also motivate the monitoring of bank risk at country level.

Given this background, the main objective of the paper is to document the evolution of country level banking risk indices. The central questions addressed here are: (1) Does this risk measure provide useful information on the buildup of risk?; (2) Does it render utile insights into market sentiments?; (3) Can it perform better than regulatory measure of prudential risk?; and (4) Is there strong dependence among countries banking sector?

As it turns out, country level DtDs are simple, convenient and intuitive forward looking risk measures. The level of $D t D$ differentiates countries based on the structural differences in their financial sectors and shows strong correlations with national and regional market sentiments. The improved informational content helps it outperform the regulatory risk measures based at European level and the causal linkages run from aggregate country level $D t D$ s to Euro wide regulatory indicators. The country level $D t D$ s do show very high correlations but causality and connectedness tests reveal no systemic component. This supports our argument of the need to measure risk indices at country level.

This paper contributes to the literature in several ways: (1) we use a novel bottom-up approach to understanding systemic risk buildup in the banking sector and risk-shifting behavior in EMU countries; (2) we use one of the most comprehensive representative databases for the EMU financial sector; (3) we do not neglect the banking sector of smaller countries, which may not be relevant at EMU level but will be relevant at country level; and 
(4) to our knowledge, this is the first paper which tries to establish a link between country-specific buildup of financial risk with euro-wide aggregate risk indicators and national and regional market sentiments.

The rest of the paper is organized as follows. Section 2 reviews the prior literature that used different frameworks to understand bank fragility and justifies our selection of $D t D$ as banking risk indicator. Section 3 describes the sample data used to construct, analyze and calibrate the individual and aggregate $D t D$ series. Section 4 first documents the behavior of returns, volatility and $D t D$ for each EMU country; it then analyses these behaviors jointly and presents some cross-sectional econometric analysis to gauge the predictive ability and market association of the country-specific DtD indicators. Section 5 documents the connectedness among country level banking risk. Section 6 draws conclusions.

\section{Choice of risk indicator}

Based on the survey of the existing risk measure techniques, we employed three basic criteria for indicator selection. It should: (1) identify the existing balance sheet fragility; (2) incorporate uncertainty using forward looking market measure; and (3) provide quantifiable risk indicators to assess relative creditworthiness (Gapen et al. (2005)). A comprehensive literature survey suggest that most of bank risk indicators can be classified into two broad categories.

The first or the traditional approach to assess the risk of a firm are based on the pure balance sheet data (see Altman (1968), Altman and Katz (1976), Kaplan and Urwitz (1979), Ohlson (1980), Zmijewski (1984), Blume et al. (1998) among others). Key accounting ratios are identified and using multivariate discriminant or multinomial choice models, firm's default probability is estimated. However the consensus on the accuracy and stress prediction ability of these indicators are relatively low.

These models have generally been criticized on three grounds: (1) the absence of a underlying theoretical model; (2) the timeliness of the information; ${ }^{2}$ and (3) the lack of uncertainty and forward-looking component. The selected methodologies also introduce sample selection bias, generating

\footnotetext{
${ }^{2}$ These models use information from financial statements which are based on past performance and are available only at a quarterly or an annual frequency; thus, they fail to capture changes in the financial conditions of the borrowing firm.
} 
inconsistent coefficient estimates (e.g., Shumway (2001), Chava and Jarrow (2004), Thomas et al. (2012)).

The second approach is pure market based. These are indices determined directly in the market place (e.g. stock prices, aggregate realized volatility, aggregate market leverage, turbulence (a measure of excess volatility relative to market), liquidity ratios and credit condition (e.g., credit default swaps)). Most of these measures lack an underlying theoretical framework but the timely availability and continuous incorporation of information helps improve the relative performance and predictive ability in some cases (see Agarwal and Taffler (2008), Campbell et al. (2011), Gropp et al. (2006), Jorion (2006), Vassalou and Yuhang (2004)).

In between these measures lies the contingent claims based model (CCA) of Merton (1974) which provides a theoretical underpinning and answers some of these criticisms. The basic model is based on the priority structure of balance sheet liabilities and uses the standard Black-Scholes option pricing formula to value the junior claims as call option on firms' value with the value of senior claims as default barrier. The structural underpinning and the combination of market-based and accounting information helps obtain a comprehensive set of financial risk indicators, e.g: DtD, probabilities of default, credit spreads, etc.

Additionally, this measure captures the current period instability (using volatility), a forward-looking component (using stock prices) and balance sheet mismatch (using capital structure), in accordance with our requirements. It has been widely applied to assess the ability of corporates, banks and sovereigns to service their debt. Banking applications follow CCA by interpreting a bank's equity as a call option on its value given the limited liability of shareholders. This approach was further refined by Vasicek (1984) and Crosbie and Bohn (2003) and is applied professionally in Moody's KMV to predict default.

The $D t D$ approach has been widely cited and reviewed by the International Monetary Fund (IMF), European Central Bank (ECB) and Office of Federal Research (OFR) as a tool for enhancing bank risk analysis. A number of applications of this approach have been studied to analyze different dimensions of risk. Several papers have examined the usefulness of $D t D$ as a tool for predicting corporate and bank failure (Jessen and Lando (2015), Koutsomanoli-Filippakia and Mamatzakis (2009), Qia et al. (2014), Kealhofer (2003), Oderda et al. (2003), Vassalou and Yuhang (2004), Gropp et al. (2006), Harada et al. (2010), Thomas et al. (2012)). They have found 
$D t D$ to be a powerful measure to predict bankruptcy and rating downgrades. Comparative analysis of DtD (Hillegeist et al. (2004), Campbell et al. (2008), Bharath and Shumway (2008), Vassalou and Yuhang (2004), Jessen and Lando (2015) and Agarwal and Taffler (2008)) also suggests that $D t D$ can be a powerful proxy to determine default.

\subsection{Calculation methodology}

The foundation for this model lies with the structural model of default developed by Black and Scholes (1973) and Merton (1974). Since equity is a junior claim to debt, it can be modeled and calculated as a standard call option on the assets with exercise price equal to the value of risky debt (also known in the literature as distress barrier or default barrier).

The model uses no arbitrage conditions and assumes a frictionless market. The stochastic process generating the firm's assets return are described by the diffusion process with a constant variance per unit time $\left(\sigma_{A}\right)$. Following standard literature, we assume that financial distress and bankruptcy are costless. ${ }^{3}$ A firm has a simple capital structure with $N$ shares of common stock with market capital $E$ and zero coupon bonds with a face value of $D$ with time to maturity $T$. The estimation methodology is as follows.

We use the value conservation equation:

$$
A=E+D e^{-r T}
$$

Given the assumption of assets distributed as a Generalized Brownian Motion, the application of the standard Black-Scholes option pricing formula (Black and Scholes (1973)) yields the closed-form expression:

$$
E=A N\left(d_{1}\right)-e^{-r T} D N\left(d_{2}\right)
$$

where $r$ is the risk-free rate under risk-neutrality, and $N(*)$ is the cumulative normal distribution. The values of $d_{1}$ and $d_{2}$ are expressed as:

$$
\begin{gathered}
d_{1}=\frac{\ln \left(\frac{A}{D}\right)+\left(r+0.5 \sigma_{A}^{2}\right) T}{\sigma_{A} \sqrt{T}} \\
d_{2}=d_{1}-\sigma_{A} \sqrt{T}
\end{gathered}
$$

\footnotetext{
${ }^{3}$ Here we assume that equity market price will reflect the cost of bankruptcy.
} 
The Merton model uses an additional equation that links the asset volatility $\sigma_{A}$ to the volatility of the bank's equity $\sigma_{E}$ by applying Ito's Lemma:

$$
\sigma_{E}=N\left(d_{1}\right) \frac{A}{E} \sigma_{A}
$$

Using Eqs. 2 and 5, we obtain the implied asset value $A$ and volatility $\sigma_{A}$, by inverting the two relationships. Once numerical solutions for $A$ and $\sigma_{A}$ are found, the $T$ periods ahead DtD is calculated as:

$$
D t D=\frac{A-D}{\sigma_{A} A}
$$

$D t D$ can be interpreted as the number of standard deviations the value of a firm's asset is away from its default barrier. This standardization across firm size and volatility can be used to rank firms in terms of their relative credit worthiness. The three key inputs in calculating the $D t D$ (market capitalization, debt, and the volatility of equity) implies that it can be influenced by the leverage ratio (debt/(equity + debt)) and volatility of the firm. A higher value of DtD can be obtained either because the leverage of the firm is low or because the volatility is low or both (Figure 3).

[Figure 3 about here.]

As can be noted, at a fixed level of volatility and low levels of leverage, $D t D$ changes are small and insignificant for changes in leverage; while for a constant level of leverage, $D t D$ shows much sharper drops for changes in equity volatility. This implies that more than leverage, it is equity volatility that has a greater influence in driving large changes in $D t D$ (Thomas et al. (2012)). Note that here we don't intend to improve the performance of this risk measure technique but aim to use it more effectively in order to capture the banking sector fragility. This approach will help supplement the existing methodologies that failed to capture vulnerabilities prior to this crisis.

\section{Data}

The sample selection methodology is as follows: First, an exhaustive list of all listed and delisted monetary financial institutions is selected from Bankscope $^{4}$ database (as on $10^{\text {th }}$ February 2014). We obtain a total of 199

\footnotetext{
${ }^{4}$ It provides a comprehensive balance sheet data for financial companies.
} 
firms in western Europe. Secondly, only firms whose shares were publicly listed and traded between the last quarter of 2004 till the second quarter of 2013 and are headquartered in EMU countries are selected. Finally, credit institutions which are pure-play insurance, pension or mortgage banks are removed. To formalize this decision, we use Datastream as an additional source of information. The major reason for this exclusion is the difference in liability structure and business model compared to banks. However it doesn't mean that they are less risky to the financial system.

This choice also ensures that the selected banks share the same accounting currency. However, it does not mean that they have a similar exchange rate risk profile, since the level of foreign currency exposure will depend on their respective asset profiles. The market-based data include daily observations of risk-free interest rates, daily stock price and total outstanding share in public. The list of variables and data sources are summarized in Table 1.

[Table 1 about here.]

Firms which were listed, delisted, nationalized or suffered any other relevant corporate actions are considered in the data set until they stopped trading on public exchanges. Due to the varying number of corporate actions every quarter, the number of firms in the sample changes over time, both for the full sample and for individual countries (Figure 4) though the core banks remains the same over time. They have an aggregate weight of $78 \%$ at the beginning of 2006 and of $86 \%$ at the end of it 2013-Q2. Therefore, we honestly do not think that changes in the bank sample composition over time may have a relevant impact on the forecasting properties of the dataset. The comprehensive list of firms used in this analysis is summarized in Table $2 .^{5}$ This detailed list of firms represents one of the best references for the EMU banking sector.

[Table 2 about here.]

[Figure 4 about here.]

Computation of individual DtD: DtD is not measured directly; it is recovered implicitly from the balance sheet and market price of firm's liabilities.

\footnotetext{
${ }^{5}$ The period for which each firm was traded is also available but is not presented here in order to save space. This information is available from the authors upon request.
} 
For our analysis we compute $D t D$ at quarterly frequency. In practical terms, this means that the balance sheet information has to be modified from its original quarterly, half-yearly, or in few cases, yearly frequencies using cubic spline interpolation. Also the real debt contracts are not all written with a single terminal date. To overcome this problem, a common procedure used by Moody's KMV (Vasicek (1984)) and also employed here, is to adopt a one year horizon $(T=1)$, but to weight longer term debt (maturity $>1$ year) at only $50 \%$ of face value. The debt barrier $(D)$ will then be equal to the face value of short-term liabilities plus half of the long-term liabilities. Equity value of the firm $(E)$ is computed as the quarterly average of daily market capitalization (number of common shares $\mathrm{x}$ share prices) while quarterly historical volatility based on daily log-returns is taken as equity volatility $\left(\sigma_{E}\right)$. The individual $D t D$ is then calibrated using the procedure outlined in Section 2.

Aggregating DtD series: In practice, the extension of DtD series as a system wide indicator has two major difficulties: (1) At what level should they be aggregated? Since we aim to focus on country level risk measurement in EMU, we would aggregate the DtD at country level; and (2) How can individual banks' data be aggregated as a system-wide representation? Here we follow Saldias (2013), Harada and Ito (2008) and Harada et al. (2010), and take the simple cross-sectional equal-weighted average at each point in time for all banks headquartered in a particular country as the aggregated risk measure. The simple average $D t D$ for country $i$ at time $t$ is represented by $a D t D_{i, t}$ :

$$
a D t D_{i, t}=(1 / N) \sum_{j=1}^{N} D t D_{j, t}
$$

where $D t D_{j, t}$ is the individual $D t D$ for firm $j$ at time $t$ having headquarter in country $i$.

This aggregation approach offers relative risk measures and is very attractive in terms of policy advice. However, this methodology has two major drawbacks. First, it ignores the latest modifications in $D t D$ measurements to improve its relative performance (see Jessen and Lando (2015), Gray and Malone (2008) and Saldias (2013)). Since our focus is not on performance improvement of $D t D$, we took the most basic and intuitive measure to understand bank risk. Secondly, it doesn't incorporate the joint distribution properties (see Gray et al. (2007), Gray and Jobst (2010), Duggar and Mitra 
(2007), Gray et al. (2010) and Jobst and Gray (2013)). Since our aim here is to evaluate the underlying linkages among country level risk, we don't incorporate a priori dependence structure among banking institutions in our aggregation technique.

Country-level aDtD: To visualize the country-wise banking risk behavior, we plot the $a D t D$ for individual EMU countries (Figure 5). As can be seen, the level of $a D t D$ differs considerably across countries. The series together show a trend and the variability across time is high. The pre-crisis level of $a D t D$ is high (above 4) for almost all countries with Greece, Austria and Ireland at the lower end. During the crisis period, all countries saw corrections in $a D t D$ with Ireland, the Netherlands, Austria and Greece showing huge drops in aDtD level. Post 2007-08, the graph also suggest that the level of $a D t D$ remain low for most of the countries suggesting that it is able to catch the trend and fluctuations during the current crisis.

[Figure 5 about here.]

\section{Analysis}

\subsection{Does aDtD provide information regarding risk buildup?}

As banking stress indicators, we compare the evolution of $a D t D$ with banking sector equity and volatility indices. ${ }^{6}$ Figure 6 plots aDtD, bank equity index and volatility for each EMU country separately. The left axis represents the equity index level while the right axis represents the annualized volatility in percentage. The level of $a D t D$ is scaled to show the general trend and variation with time. The graphs suggest that $a D t D$ started deteriorating for most countries between 2006-07, except for France and the Netherlands. Notably, it started declining when bank index level showed an upward trend while volatility was quite stable. ${ }^{7}$

\footnotetext{
${ }^{6}$ The country wise bank equity index is based on average logarithmic returns of all publicly traded banking firms headquartered in a particular country and are normalized to 100 for all countries at the beginning of the last quarter in 2004. The volatility is equal weighted annualized equity price volatility based on the standard deviation of daily logarithmic returns of the previous quarter. This methodology creates an upward (downward) bias in the returns (volatility) indices due to bank failures and should be interpreted carefully.

${ }^{7}$ It also indicates strong correlations with the average volatility, which undermines its effectiveness.
} 
[Figure 6 about here.]

The returns level suggests that the bank equity prices have fallen substantially for all countries. The first period of rapid decline started around mid 2007, though some recovery was seen in 2009. The second period of decline started during the sovereign debt crisis at the end of 2009, and still continues for some countries. For almost half of the sample, the index level at the end of 2012 is below the index value at the end of 2004. Greece, Belgium, Ireland, Portugal and Italy witnessed the highest drop while Finland and Austria were largely unaffected. In some countries (like Portugal and Ireland) the index level shows a dramatic recovery post crisis. These spikes are due to the sudden drop in sample size due to bank failures and are therefore more notable for small countries having fewer banks.

The volatility of small countries (Greece, Portugal, Ireland, the Netherlands and Austria) is relatively high. Post 2009, the volatility dropped for most EMU countries but has not yet returned to its pre-crisis level. European sovereign debt crisis, loss of market confidence and the need for continuous monetary support to banking sector may be explanations for the relatively high average volatility in peripheral countries. Given the changes in the sample size in a few peripheral countries, the shift in the mean volatility level needs to be interpreted with caution.

Equity indices and aDtD during the crisis: To compare the performance of equity indices with $a D t D$ during the crisis, we analyze the country-wise behavior of market returns with $a D t D$ during the financial crisis. As a predictive indicator of future health, we examine the possibility by comparing the cumulative returns from 2007-Q2 and 2008-Q2 to 2009Q1 with the fall in level of $a D t D$ indicator in each country. Figure 7 a summarizes this information aptly. As can be seen, most of the fall in aDtD occurred between 2007-Q2 and 2008-Q2, indicating a direct obvious prediction of vulnerability prior to the crisis. However, the total drop in returns shows no correlation with the drop in $a D t D$.

Do initial level of aDtD matters?: Whether or not the initial level of $a D t D$ matters, we plot the initial level of $a D t D$ with the drop in $a D t D$ during the crisis (Figure $7 \mathrm{~b}$ ) and find a positive relationship. This suggests that higher initial levels of $a D t D$ experienced higher corrections during this period. The $a D t D$ for most EMU countries averaged between 4 to 5 prior to the crisis. During the crisis (between 2007-Q2 and 2009-Q1), it fell sharply for Austria, France and Italy while for Portugal, Spain and Greece, the cor- 
rections were lower than expected.

[Figure 7 about here.]

\subsection{Does aDtD render utile insights into market sentiments?}

Here we explore the association of $a D t D$ with a selection of indicators covering broad market sentiments and sectoral bank indices collected from independent agencies, professional market data providers and other academic authors.

At country level: We consider six variables as proxy for market sentiment: a consumer confidence indicator (CCI), stock returns (RET), the credit rating (RAT), a fiscal stance indicator (FSI), stock volatility (VOL), rating (RAT) and an index of economic policy uncertainty (EPU). As for the national bank indices, we examine two sectoral equities indices covering banks and financial services (Table 3 ).

Table 4 shows that for the individual countries we find a positive association between $a D t D, C C I$ and RET. In 7 out of 11 cases we detect a strong connection between our indicator and CCI, while for the RET we obtain a moderate or strong relationship in 6 out of 11 . We also find a relatively moderate negative association with RAT and EPU and a strong negative correlation with VOL. For FSI we obtain mixed results. For the sectoral bank indices, regardless of the $D t D$ indicator, our results suggest a moderate positive association with both DSBANKS and DSFIN. The findings suggest that $a D t D$ s are capturing the underlying trends that generate differences in risk perceptions of national banking system.

[Table 3 about here.]

[Table 4 about here.]

At regional (Eurozone) level: We did a similar exercise to understand the association between regional market sentiments and financial indicators with $a D t D$. We find a strong positive association between $a D t D$ s and the regional consumer confidence indicator and a strong negative relationship with regional economic policy uncertainty and regional financial market volatility. The associations with the indicator of credit quality in the EMU corporate market and regional fiscal stance are moderate and positive while their connection with regional interest rate volatility (1-year forward) is mixed. 
Regarding the regional sectoral bank indices, there is evidence of a strong association with $a D t D \mathrm{~s}$ in most cases. Interestingly, the $a D t D \mathrm{~s}$ in the peripheral countries strongly influence all EMU bank indices (both GIIPS ${ }^{8}$ and non-GIIPS), suggesting a strong co-movement tendencies among banking indices. $^{9}$

\subsection{Can aDtD perform better than regulatory measure of prudential risk?}

We examine how country-wise aDtD perform with respect to the European SIFI based aggregate banking risk indicator (ECB DtD) used by the European Central Bank. To check the better predictive ability of aDtD, we plot the ECBDtD together with $a D t D$ in Figure 5. The graphical evidence suggests that $a D t D$ s do suggest the deteriorating market conditions in most peripheral EMU countries (Spain, Ireland, Greece and Italy) and some central countries (Germany, Belgium and Finland) prior to the ECBDtD. ${ }^{10}$

An additional dimension of considering comprehensive list of banks for each country is the increased informational content. To test whether this has a significant effect, we create a time-series of average $D t D$ of all EMU banks in our sample (EMU-aDtD) and explore its relationship with the EMU macroeconomic uncertainty indicators compiled by the European Central Bank (2013) from a set of diverse sources: (1) measures of uncertainty perceived by economic agents about the future economic situation based on surveys; (2) measures of uncertainty or of risk aversion based on financial

\footnotetext{
${ }^{8}$ Greece, Ireland, Italy, Portugal and Spain.

${ }^{9}$ Complete detail of regional indices and correlations are not attached to save space but are available upon request.

${ }^{10}$ Further results (not shown here, but available from the authors upon request) suggest that default risk might be higher in the case of multinational rather than domestic oriented banks. ECB's calculation of DtD based on SIFIs also suggests that the level of aggregate $D t D$ is low for SIFI. This is important, since multinational banks not only mean more interconnectedness, but also serve as buffer of regional shocks (Belke and Gros (2015)). Indeed, cross-border capital flows in the form of equity appear to be much more stable than those taking the form of credit, especially inter-bank credit. Moreover, credit booms and bust leave a debt overhang and losses can materialize only via insolvencies, whereas equity flows absorb automatically losses in case of a bust and provide the cross border owner with incentives to continue to provide financing. It follows that cross-border banks can absorb regional shocks. But large banks pose the 'too big to fail' problem and they would also propagate regional shocks, especially if they originate in large countries, to the entire area (Belke (2013), Belke and Gros (2015)).
} 
market indicators; and (3) measures of economic policy uncertainty. As far as the EMU banking risk measure is concerned, we use the ECBDtD.

Regarding the measures of uncertainty related to future economic outcomes, we use the degree of disagreement about the projections for activity between professional forecasters measured as the standard deviation of the projections from Consensus Economics for annual real GDP growth in the following calendar year (ECBANY), the average "aggregate uncertainty" from the ECB's Survey of Professional Forecasters (ECBBAVE), combining both disagreement between forecasters and individual uncertainty, and an indicator capturing the uncertainty of private households (ECBCHOU) and enterprises (ECBCBUS) based on the European Commission's Business and Consumer Surveys. Additionally, to account for the concerns for the stability of the euro we have used the indicator built up by Klose and Weigert (2012) which reflects the market expectation of the probability that at least one euro area country will have left the currency union by the end of 2013 (EUROINST).

To assess financial market uncertainty or risk aversion measures, we use an average of a set of financial market indicators (implied bond and stock market volatility, implied EUR/US dollar volatility and CDS spreads over government bond yields) and a number of systemic stress indicators (exchange rate volatility, equity market volatility, bond market volatility, money market volatility, financial intermediation and a composite systemic stress indicator) (ECBDAVE).

With respect to economic policy uncertainty, we use an index based on the newspaper coverage of policy-related economic uncertainty and the disagreement between forecasters with regard to the outlook for inflation and budget balances: These components are aggregated using weights of $50 \%$ for the former and $25 \%$ for each of the dispersion measures (ECBEAVE). Additionally, we make use of an indicator that combines all the individual sets of series by principal component analysis (ECBFPC). We select these measures of uncertainty because they show a significant negative correlation with key macroeconomic variables, such as quarterly growth rates of real GDP, total investment, private consumption and, in particular, total employment.

Table 5 summarizes the correlations of these ECB regulatory indicators with EMU-aDtD. As can be seen, we find a significant and negative association between our indicators of EMU banking risk based on DtD and the various measures of macroeconomic uncertainty, suggesting that higher banking risk (signaled by a reduction in $D t D$ ) will increase macroeconomic 
uncertainty and, as a consequence, adversely affect macroeconomic events.

To test the predictive ability of this indicator with respect to the regulatory indicators, we assessed the possible existence of Granger-causality. As can be seen in Table 6, with the sole exception of ECBCHOU, we find a significant unidirectional Granger-causality relationship running from our indicators of EMU banking risk to both the various measures of macroeconomic uncertainty and the banking risk indicator used by the ECB. This result gives further support to the hypothesized interconnection between $D t D \mathrm{~s}$ and macroeconomic uncertainty and banking risk.

[Table 5 about here.]

[Table 6 about here.]

Summary: Our empirical estimates using country level indices suggest that the country-wise $a D t D$ has better predictive ability than the market based measures (returns and volatility) and is strongly connected with market sentiments at national and regional level. The initial level of $a D t D$ matters and the drop is more significant for countries having higher $a D t D$. aDtD also have strong correlations with regulatory measures of risk and has higher information content. The direction of causality runs from aDt $D$ to regulatory measures.

\section{Connectedness among countries banking risk}

In this section, we explore the linkages between $a D t D$ using a cross country connectedness measures. We use three ways to measure the connectedness: (1) Correlations; (2) Granger causality; and (3) Diebold-Yilmaz connectedness index (DYCI) based on the variance decomposition of forecast errors.

\subsection{Correlation measures}

To understand the co-movement properties, we use three correlation measures (parametric: Pearson, and non-parametric: Spearman and Kendell) in our analysis. ${ }^{11}$ Since the Pearson measure is the most commonly used, we report our findings based on Pearson correlations only, but they are also robust based on other measures.

\footnotetext{
${ }^{11}$ This avoids any bias arising from potential non-linear dependencies and confirms the robustness of our findings.
} 
[Table 7 about here.]

For each measure of correlations, we first estimate the pair-wise correlations between the $a D t D$ (Table 7). As can be seen, we find a strong correlation $^{12}$ between indices, which suggests a common risk factor. This may also be due to the small sample, which contains two crisis episodes. To understand the time varying correlation dynamics, we tested for correlations using pre-/post crisis windows and apply a signed rank test to evaluate the null hypothesis that the mean and median correlations are equal if we divide the time period in two half (pre and post 2009-Q4).

The results suggest that except Germany and Finland, all other countries shows very strong correlations with EMU average. This also suggest a common risk factor which we test in the next section. Belgium, Greece, Italy and Portugal have strong inter-linkages and connections across the board. Belgian banking sector shows strong connections with all EMU countries except Germany and the Netherlands. Germany is strongly connected with only Italy and moderately to France, Austria and Finland. For other peripheral countries, Germany has weak correlations.

\subsection{Granger causality}

The graphic behavior of the countries' aDtD series and correlation estimates suggests an underlying trend. It may be due to an increase in the systemic risk of global financial industry due to cross linkages, increased volatility or investment in correlated assets. To understand this spillover within the EMU banking sector, we run Granger causality tests for each pair-wise country aDtDs. We find very weak evidence of causality running from a particular country towards the rest of the countries (Figure 8), which suggests that the banking risk captured by countries' aDtDs remains idiosyncratic (suggestive evidence of no systemic component). To test the robustness of our results, we also did the analysis based on banks' market capital and asset based weighted average $D t D$. The results (not shown here to save space, but they are available from the authors upon request) render the same qualitative conclusions than in the case of using aDtDs.

[Figure 8 about here.]

\footnotetext{
${ }^{12}$ We use the adjective "strong" when the absolute value of the correlation is above 0.8 , "moderate"when it is between 0.7-0.8, and "weak" when it is between 0.6-0.7.
} 


\subsection{Diebold-Yilmaz connectedness measure}

To explore further the systemic underlying component among aDtD indices, we use VAR (vector auto regression) methodologies based measure of connectedness. The connectedness is based on the decomposition of the forecast error variance, which is briefly described here. For a multivariate time series, the forecast error variance decomposition works as follows: First, we fit a standard vector autoregressive (VAR) model to the series; secondly, using series data up to, and including, time $t$, establish an $H$ period ahead forecast (up to time $t+H$ ); and finally, decompose the forecast error variance for each component with respect to shocks from the same or other components at time $t$.

Consider an N-dimensional covariance-stationary data-generating process (DGP) with orthogonal shocks:

$$
x_{t}=\Theta(L) u_{t}, \Theta(L)=\Theta_{0}+\Theta_{1} L+\Theta_{2} L^{2}+\ldots, E\left(u_{t}, u_{t}^{\prime}\right)=I
$$

Note that $\Theta_{0}$ need not be diagonal. All aspects of connectedness are contained in this very general representation. Contemporaneous aspects of connectedness are summarized in $\Theta_{0}$ and dynamic aspects in $\Theta_{1}, \Theta_{2}, \ldots$ Transformation of $\Theta_{1}, \Theta_{2}, \ldots$ via variance decompositions in needed to reveal and

compactly summarize connectedness. Let us denote by $d_{i j}^{H}$ the $i j$-th $H$ step variance decomposition component (i.e., the fraction of variable $i$ 's $H$ step forecast error variance due to shocks in variable $j$ ). The connectedness measures are based on the "non-own" or "cross" variance decompositions, $d_{i j}^{H}, i, j=1, \ldots, N, i \neq j$.

Diebold and Yilmaz (2014) propose several connectedness measures built from pieces of variance decompositions in which the forecast error variance of variable $i$ is decomposed into parts attributed to the various variables in the system. Here we provide a snapshot of their connectedness index. They proposed a connectedness table such as Table 8 to understand the various connectedness measures and their relationships. Its main upper-left $N \mathrm{x} N$ block, that contains the variance decompositions, is called the "variance decomposition matrix," and is denoted it by $D^{H}=\left[d_{i j}\right]$ The connectedness table augments $D^{H}$ with a rightmost column containing row sums, a bottom row containing column sums, and a bottom-right element containing the grand average, in all cases for $i \neq j$.

[Table 8 about here.] 
The off-diagonal entries of $D^{H}$ are the parts of the $N$ forecast-error variance decompositions of relevance from a connectedness perspective. In particular, the gross pairwise directional connectedness from $j$ to $i$ is defined as follows:

$$
C_{i \leftarrow j}^{H}=d_{i j}^{H}
$$

Since in general $C_{i \leftarrow j}^{H} \neq C_{j \leftarrow i}^{H}$ the net pairwise directional connectedness from $j$ to $i$, can be defined as:

$$
C_{i j}^{H}=C_{j \leftarrow i}^{H}-C_{i \leftarrow j}^{H}
$$

Regarding the off-diagonal row sums in Table 8, they give the share of the $H$-step forecast-error variance of variable $x_{i}$ coming from shocks arising in other variables (all other, as opposed to a single other), while the offdiagonal column sums provide the share of the $H$-step forecast-error variance of variable $x_{i}$ going to shocks arising in other variables. Hence, the offdiagonal row and column sums, labeled "from" and "to" in the connectedness table, offer the total directional connectedness measures. In particular, total directional connectedness from others to $i$ is defined as

$$
C_{i \leftarrow \bullet}^{H}=\sum_{j=1, j \neq i}^{N} d_{i j}^{H}
$$

The total directional connectedness to others from $i$ is defined as

$$
C_{\bullet \leftarrow i}^{H}=\sum_{j=1, j \neq i}^{N} d_{j i}^{H}
$$

We can also define net total directional connectedness as

$$
C_{i}^{H}=C_{\bullet \leftarrow i}^{H}-C_{i \leftarrow \bullet}^{H}
$$

Finally, the grand total of the off-diagonal entries in $D^{H}$ (equivalently, the sum of the "from" column or "to" row) measures total connectedness:

$$
C^{H}=\frac{1}{N} \sum_{i, j=1, j \neq i}^{N} d_{i j}^{H}
$$

For the case of non-orthogonal shocks the variance decompositions are not easily calculated as before because the variance of a weighted sum is not 
an appropriate sum of variances; in this case methodologies for providing orthogonal innovations like traditional Cholesky-factor identification may be sensitive to ordering. So, following Diebold and Yilmaz (2014), a generalized VAR decomposition (GVD), invariant to ordering, proposed by Koop et al. (1996) and Pesaran and Shin (1998) will be employed. The $H$-step generalized variance decomposition matrix is defined as $D^{g H}=\left[d_{i j}^{g H}\right]$, where

$$
d_{i j}^{g H}=\frac{\sigma_{i j}^{-1} \sum_{h=0}^{H-1}\left(e_{i}^{\prime} \Theta_{h} \sum e_{j}\right)}{\sum_{h=0}^{H-1}\left(e_{i}^{\prime} \Theta_{h} \sum \Theta_{h}^{\prime} e_{j}\right)}
$$

In this case, $e_{j}$ is a vector with $j^{\text {th }}$ element unity and zeros elsewhere, $\Theta_{h}$ is the coefficient matrix in the infinite moving-average representation from VAR, $\sum$ is the covariance matrix of the shock vector in the nonorthogonalized-VAR, $\sigma_{i j}$ being its $j^{\text {th }}$ diagonal element. In this GVD framework, the lack of orthogonality makes it so that the rows of do not have sum unity and, in order to get a generalized connectedness index $\tilde{D}^{g}=\left[\tilde{d}_{i j}^{g}\right]$, the following normalization is necessary: $\tilde{d}_{i j}^{g}=d_{i j}^{g} / \sum_{j=1}^{N} d_{i j}^{g}$, where by construction $\sum_{j=1}^{N} \tilde{d}_{i j}^{g}=1$ and $\sum_{i, j=1}^{N} \tilde{d}_{i j}^{g}=N$. The matrix $\tilde{D}^{g}=\left[\tilde{d}_{i j}^{g}\right]$ permits us to define similar concepts as defined before for the orthogonal case, that is, total directional connectedness, net total directional connectedness and total connectedness.

Tables 9 and 10 present the connectedness tables for $a D t D$ based on six months and one year horizon, along with the nonparametrically bootstrapped standard errors, while Figure 9 shows the most important directional connections among the pairs of $12 a D t D$ s based on the top three deciles. As can be seen, all the connectedness measures are statistically different from zero at least at the $5 \%$ level. To test the robustness of our results, we also did the analysis based on banks' market capital and asset based weighted average $D t D$. The results (not shown here to save space, but they are available from the authors upon request) render the same qualitative conclusions than in the case of using aDtDs.

The Netherlands show very weak connectedness while Germany and Italy shows linkages only with Finland and Portugal respectively. Spain, Belgium, Portugal and Austria have high connectedness with most EMU countries except for the Netherlands, Italy and Germany. Even for changing horizon, the results remain quite consistent. In most cases, the effects seem to dry out but the connectedness pair remain the same. Finally, we observe a value of $73.67 \%$ for the total connectedness between $a D t D$ in a horizon of 6 months 
and value $76.72 \%$ for a year, in line with the values of $78.3 \%$ obtained by Diebold and Yilmaz (2014) for US financial institutions.

[Table 9 about here.]

[Table 10 about here.]

[Figure 9 about here.]

\section{Conclusion}

By analyzing the behavior and fluctuations of a market based banking risk indicator for individual EMU countries, we find that $a D t D$ is an intuitive, simple and convenient forward looking risk measure. The level of $a D t D$ varies with country suggesting cross-sectional structural differences across the banking sector and captures trends as well as fluctuations in the financial markets. Analysis during the crisis period suggests better predictive ability (12-18 months prior to the crisis) for most of the EMU countries. The initial level of $a D t D$ matters but the change in $a D t D$ is more pronounced for countries with a higher initial level.

When compared with other regulatory risk and market sentiment measures, $a D t D$ s shows better predictive ability and very high correlations. The strong association between $a D t D$ s and regional (Eurozone) market sentiment (uncertainty)/sectoral banking indices also improves the explanatory power. The Granger causality test reveals the direction of causality running from $a D t D$ s to Eurozone risk indicators (and not the other way round) suggesting better information content.

The correlations analysis suggests strong inter-linkages across country level banking stress but low inter-linkage between core and peripheral EMU countries. Taking s step further, we tested for a systemic component using Granger causality tests and found negative results. To better understand the dependence structure, we explored further by analyzing the connectedness using Diebold-Yilmaz Connectedness Index and found low connectedness among country level banking risk indices.

As the recent literature has highlighted huge connectedness among Systemically Important Financial Institutions (SIFI) and high degree of joint risk of default, our empirical estimates which uses country level indices suggest otherwise. The country-wise $a D t D$ has higher predictive ability and 
is strongly connected with market sentiments but the connectedness among the country-wise $a D t D$ is low. Suggesting that the inter-linkages may be higher for SIFI but for the country level banking sector, the connectedness is low. This result will be beneficial for understanding and augmenting a priori dependence structure in the computation of systemic risk.

So, there are various reasons for considering country-wise risk indicators alongside regional market and other risk measures. As the statistical theory suggests, when faced with two estimators for the same underlying variable, it is optimal to combine the two. Tracking country specific indices provide additional information related to the average risk level and their ability to forecast the risk buildup cannot be ignored. Following the systemic risk indicators based on large, complex EU-wide financial institution may delay the prediction of risk buildup.

$D t D$ measures can also be extended beyond the banking context. The theoretical argument being a kind of option value of waiting under uncertainty can be extended to international trade literature to help understand the impact of uncertainty on investment, export, import and employment (see Belke and Gros (2001) for EMU case). Further extension can also help examine the interconnection between banking and sovereign risk in the euro area (Gómez-Puig et al. (2015)) and to explore if the Banking Union in the euro area can disentangling the risk of the EMU banks and their governments by influencing the risk pattern (Belke (2013), Belke and Gros (2015), De Groen (2015)).

\section{Acknowledgments}

The authors thank the editor and one anonymous referee for useful comments and suggestions on a previous draft of this article, substantially improving the content and quality of the article. We are very grateful to Analistas Financieros Internacionales for kindly providing the credit rating dataset and Fernando Fernández-Rodríguez for his research assistance. We thank Scott R. Baker, Raquel Lopez, Eliseo Navarro, Vito Polito, Michael R. Wickens and the European Cenral Bank for allowing us access to their datasets. We also thank $6^{\text {th }}$ International IFABS Conference participants and especially Stefan Eichler and Karol Sobański for helpful comments. This paper is based upon work supported by the Government of Spain under grant numbers ECO2011-23189 and ECO2013-48326 and Fundación Banco Sabadell. 


\section{References}

Agarwal, V., Taffler, R., 2008. Comparing the performance of market based and accounting based bankruptcy prediction models. Journal of Banking and Finance 32 (8), 1541-1551.

Altman, E., 1968. Financial ratios, discriminant analysis and the prediction of corporate bankruptcy. Journal of Finance 23 (4), 589-609.

Altman, E., Katz, S., 1976. Statistical bond rating classification using financial and accounting data. In: Schiff, M., and Sorter, G. (Eds.). Proceedings of the Conference on Topical Research in Accounting, New York University Press, New York, 205-239.

Belke, A., 2013. Towards a genuine Economic and Monetary Union - Comments on a roadmap. Politics and Governance 1 (1), 48-65.

Belke, A., Gros, D., 2001. Real impacts of intra-European exchange rate variability: A case for EMU? Open Economies Review 12 (3), 231-264.

Belke, A., Gros, D., 2015. Banking Union as a shock absorber. Ruhr Economic Paper 548, Ruhr-Universität Bochum.

Belke, A., Schneider, J., 2013. Portfolio choice of financial investors and European business cycle convergence: a panel analysis for EU countries. Empirica 40 (1), 175-196.

Bharath, S. T., Shumway, T., 2008. Forecasting default with the Merton distance to default model. Review of Financial Studies 21 (3), 1339-1369.

Black, F., Scholes, M., 1973. The pricing of options and corporate liabilities. Journal of Political Economy 81 (3), 637-654.

Blume, M., Lim, F., Mackinlay, A., 1998. The declining credit quality of U.S. corporate debt: myth or reality? Journal of Finance 53 (4), 1389-1413.

Campbell, J., Hilscher, J., Szilagyi, J., 2008. In search of distress risk. Journal of Finance 63 (6), 2899-2939.

Campbell, J., Hilscher, J., Szilagyi, J., 2011. Predicting financial distress and the performance of distressed stocks. Journal of Investment Management $9(2), 1-21$. 
Chava, S., Jarrow, R., 2004. Bankruptcy prediction with industry effects. Review of Finance 8 (4), 537-539.

Crosbie, P. J., Bohn, J. R., 2003. Modeling default risk. Moody's KMV. Available at http://www.defaultrisk.com/pp_model_35.htm.

De Groen, W. P., 2015. The ECB's QE: time to break the doom loop between banks and their governments. Policy Brief 328, Center for European Policy Studies.

Diebold, F. X., Yilmaz, K., 2014. On the network topology of variance decompositions: measuring the connectedness of financial firms. Journal of Econometrics 182 (1), 119-134.

Duggar, E., Mitra, S., 2007. External linkages and contagion risk in Irish banks. Working Papers 07/44, International Monetary Fund.

European Central Bank, 2013. How has macroeconomic uncertainty in the euro area evolved recently?, Monthly Bulletin October, 44-48.

Gapen, M. T., Gray, D. F., Lim, C. H., Xiao, Y., 2005. Measuring and analyzing sovereign risk with contingent claims. Working Papers 05/155, International Monetary Fund.

Gómez-Puig, M., Singh, M. K., Sosvilla-Rivero, S., 2015. Sovereigns and banks in the euro area: a tale of two crises. Working Paper 2015/04. Institut de Recerca en Economia Aplicada, Universitat de Barcelona.

Gray, D., Jobst, A., 2010. Lessons from the financial crisis on modeling systemic risk and sovereign risk. In: Berd, A. (Eds.), Lessons from the financial crisis. RISK Books, London.

Gray, D., Jobst, A., Malone, S., 2010. Quantifying systemic risk and reconceptualizing the role of finance for economic growth. Journal of Investment Management 8 (2), 90-110.

Gray, D., Malone, S., 2008. Macrofinancial risk analysis. John Wiley and Sons, Chichester, West Sussex, England.

Gray, D., Merton, R., Bodie, Z., 2007. New framework for measuring and managing macrofinancial risk and financial stability. Working Paper 13607, National Bureau of Economic Research. 
Gropp, R., Vesala, J., Vulpers, G., 2006. Equity and bond market signals as leading indicators of bank fragility. Journal of Money, Credit and Banking 38 (2), 399-428.

Harada, K., Ito, T., 2008. Did mergers help Japanese mega-banks avoid failure? Analysis of the distance to default of banks. Working Paper 14518, National Bureau of Economic Research.

Harada, K., Ito, T., Takahashi, S., 2010. Is the distance to default a good measure in predicting bank failures? Case studies. Working Paper 16182, National Bureau of Economic Research.

Hillegeist, S. A., Keating, E., Cram, D. P., Lunstedt, K. G., 2004. Assessing the probability of bankruptcy. Review of Accounting Studies 9 (1), 5-34.

Jessen, C., Lando, D., 2015. Robustness of distance-to-default. Journal of Banking and Finance 50, 493-505.

Jobst, A., Gray, D., 2013. Systemic contingent claims analysis: estimating market-implied systemic risk. Working Papers 13/54, International Monetary Fund.

Jorion, P., 2006. Bank trading risk and systemic risk. In Carey, M. and Stulz, R. M. (Eds.), The risks of financial institutions. University of Chicago Press, Chicago, 29-58.

Kaplan, R., Urwitz, G., 1979. Statistical models of bond ratings: a methodological inquiry. Journal of Business 52 (2), 231-261.

Kealhofer, S., 2003. Quantifying credit risk I: default prediction. Financial Analyst Journal 51 (1), 30-44.

Koop, G., Pesaran, M. H., Potter, S. M., 1996. Impulse response analysis in non-linear multivariate models. Journal of Econometrics 74 (1), 119-147.

Koutsomanoli-Filippakia, A., Mamatzakis, E., 2009. Performance and Merton-type default risk of listed banks in the EU: a panel VAR approach. Journal of Banking and Finance 33, 2050-2061.

Merton, R. C., 1974. On the pricing of corporate debt: the risk structure of interest rates. Journal of Finance 29 (2), 449-470. 
Oderda, G., Dacorogna, M., Jung, T., 2003. Credit risk models: do they deliver their promises? A quantitative assessment. Review of Banking, Finance and Monetary Economics 32 (2), 177-195.

Ohlson, J. A., 1980. Financial ratios and the probabilistic prediction of bankruptcy. Journal of Accounting Research 18 (1), 109-131.

Pesaran, M. H., Shin, Y., 1998. Generalized impulse response analysis in linear multivariate models. Economic Letters 58 (1), 17-29.

Qia, M., Zhangb, X., Zhao, X., 2014. Unobserved systematic risk factor and default prediction. Journal of Banking and Finance 49, 216-227.

Saldias, M., 2013. Systemic risk analysis using forward-looking distance-todefault series. Journal of Financial Stability 9 (4), 498-517.

Shumway, T., 2001. Forecasting bankruptcy more accurately: a simple hazard model. Journal of Business 74 (1), 101-124.

Thomas, S., Singh, M. K., Aggarwal, N., 2012. Do changes in distance-todefault anticipate changes in the credit rating? Working Paper 2012-10, Indira Gandhi Institute of Development Research, Mumbai.

Vasicek, O., 1984. Credit valuation. KMV Corporation, San Francisco.

Vassalou, M., Yuhang, X., 2004. Default risk in equity returns. Journal of Finance 59 (2), 831-868.

Zmijewski, M. E., 1984. Methodological issues related to the estimation of financial distress prediction models. Journal of Accounting Research 22 (Supplement), 59-82. 
Table 1: Description of variables

\begin{tabular}{|c|c|c|}
\hline Balance sheet variables & & Source \\
\hline Total assets & As reported in annual/interim reports & Bankscope (Code 2025) \\
\hline Short-term liabilities & Deposits and short term funding & Bankscope (Code 2030) \\
\hline Total equity & As reported in annual/interim reports & Bankscope (Code 2055) \\
\hline \multicolumn{3}{|c|}{ Daily market based variables } \\
\hline Risk-free interest rate & $\begin{array}{l}\text { Benchmark } 10 \mathrm{Y} \text { bond yield of country where } \\
\text { the bank headquarter is based }\end{array}$ & Thomson Datastream \\
\hline Market capitalization & $\begin{array}{l}\text { Daily closing share price multiplied by total } \\
\text { outstanding share in public }\end{array}$ & Thomson Datastream \\
\hline
\end{tabular}


Table 2: List of banks (by country)

AT - UniCredit Bank Austria AG (AT0000995006)*

AT - Erste Group Bank AG (AT0000652011)

AT - Raiffeisen Bank International AG (AT0000606306)

BE - Dexia (BE0003796134)

BE - KBC Groep NV (BE0003565737)

DE - Landesbank Berlin Holding AG (DE0008023227)*

DE - Hypothekenbank Frankfurt AG (DE0008076001)*

DE - UniCredit Bank AG (DE0008022005)*

DE - Oldenburgische Landesbank (DE0008086000)

DE - Deutsche Postbank AG (DE0008001009)

DE - UmweltBank AG (DE0005570808)

DE - Hypo Real Estate Holding AG (DE0008027707)*

DE - HSBC Trinkaus \& Burkhardt AG (DE0008115106)

DE - Deutsche Bank AG (DE0005140008)

DE - Commerzbank AG (DE000CBK1001)

DE - Wüstenrot \& Württembergische (DE0008051004)

DE - Comdirect Bank AG (DE0005428007)

DE - Net-M Privatbank 1891 AG (DE0008013400)*

DE - Merkur-Bank KGaA (DE0008148206)

DE - Quirin Bank AG (DE0005202303)

ES - Banco Santander SA (ES0113900J37)

ES - Banco Bilbao Vizcaya Argentaria SA

(ES0113211835)

ES - Caixabank, S.A. (ES0140609019)

ES - Bankia, SA (ES0113307021)

ES - Banco de Sabadell SA (ES0113860A34)

ES - Banco Popular Espanol SA (ES0113790226)

ES - Caja de Ahorros del Mediterraneo (ES0114400007)

ES - Bankinter SA (ES0113679I37)

ES - Renta 4 Banco, S.A. (ES0173358039)

FI - Pohjola Bank Plc (FI0009003222)

FI - Aktia Bank Plc (FI4000058870)

FI - Alandsbanken Abp-Bank of Aland Plc (FI0009001127)

FR - Crédit Agricole Sud Rhône Alpes (FR0000045346)

FR - Paris Orléans SA (FR0000031684)

FR - Crédit Agricole de la Touraine et du Poitou (FR0000045304)

FR - Credit Agricole Alpes Provence (FR0000044323)

FR - Crédit Agricole Nord de France (FR0000185514)

FR - Crédit Agricole d'Ile-de-France (FR0000045528)

FR - Crédit Agricole Loire Haute-Loire (FR0000045239)

FR - Crédit Industriel et Commercial (FR0005025004)

FR - Banque Tarneaud (FR0000065526)*

FR - Caisse régionale de Crédit Agricole Mutuel de Normandie-Seine (FR0000044364)

FR - Caisse Régionale de Crédit Agricole Mutuel du Languedoc (FR0010461053)

FR - Natixis (FR0000120685)

FR - Crédit Agricole de l'Ille-et-Vilaine (FR0000045213)

FR - Crédit Agricole d'Aquitaine (FR0000044547)*

FR - Société Générale (FR0000130809)

FR - Crédit Agricole S.A. (FR0000045072)

FR - BNP Paribas (FR0000131104)

27
FR - Boursorama (FR0000075228)

FR - Crédit Agricole du Morbihan (FR0000045551)

FR - Crédit Agricole Brie Picardie (FR0010483768)

FR - Société Alsacienne de Développement et d'Expansion (FR0000124315)*

GR - National Bank of Greece SA (GRS003003019)

GR - Piraeus Bank SA (GRS014003008)

GR - Eurobank Ergasias SA (GRS323003004)

GR - Alpha Bank AE (GRS015013006)

GR - Marfin Investment Group (GRS314003005)

GR - Attica Bank SA-Bank of Attica SA (GRS001003003)

GR - General Bank of Greece SA (GRS002003010)

IE - Depfa Bank Plc (IE0072559994)*

IE - Irish Bank Resolution Corp. Ltd. (IE00B06H8J93)*

IE - Permanent TSB Plc (IE0004678656)*

IE - Bank of Ireland (IE0030606259)

IE - Allied Irish Banks plc (IE0000197834)

IT - UniCredit SpA (IT0004781412)

IT - Intesa Sanpaolo (IT0000072618)

IT - Banca Monte dei Paschi di Siena SpA (IT0001334587)

IT - Unione di Banche Italiane Scpa (IT0003487029)

IT - Banco Popolare Società Cooperativa (IT0004231566)

IT - Mediobanca SpA (IT0000062957)

IT - Banca popolare dell'Emilia Romagna (IT0000066123)

IT - Banca Popolare di Milano SCaRL (IT0000064482)

IT - Banca Carige SpA (IT0003211601)

IT - Banca Popolare di Sondrio Societa Cooperativa per Azioni (IT0000784196)

IT - Credito Emiliano SpA-CREDEM (IT0003121677)

IT - Credito Valtellinese Soc Coop (IT0000064516)

IT - Banca popolare dell'Etruria e del Lazio Soc. coop. (IT0004919327)

IT - Credito Bergamasco (IT0000064359)

IT - Banco di Sardegna SpA (IT0001005070)

IT - Banco di Desio e della Brianza SpA (IT0001041000)

IT - Banca Ifis SpA (IT0003188064)

IT - Banca Generali SpA (IT0001031084)

IT - Banca Intermobiliare di Investimenti e Gestioni (IT0000074077)

IT - Banca Popolare di Spoleto SpA (IT0001007209)

IT - Banca Profilo SpA (IT0001073045)

IT - Banca Finnat Euramerica SpA (IT0000088853)

NL - SNS Reaal NV (NL0000390706)*

NL - RBS Holdings NV (NL0000301109)*

NL - ING Groep NV (NL0000303600)

NL - Delta Lloyd NV-Delta Lloyd Group (NL0009294552)

NL - Van Lanschot NV (NL0000302636)

NL - BinckBank NV (NL0000335578)

PT - Montepio Holding SGPS SA (PTFNB0AM0005)*

PT - Banco Comercial Português, SA (PTBCP0AM0007)

PT - Banco Espirito Santo SA (PTBES0AM0007)

PT - Banco BPI SA (PTBPI0AM0004)

PT - BANIF, SA (PTBAF0AM0002)

Parenthesis contains the ISIN (International Securities Identification Number), an asterisk $\left(^{*}\right)$ mark represents companies which got delisted during the study period. SIFI are indicated in italics (based on Bank of International Settlements G-SIBs as of November 2014). 
Table 3: National financial indicators

\begin{tabular}{|c|c|c|}
\hline \multicolumn{3}{|c|}{ Market sentiment indicators } \\
\hline Variable & Description & Source \\
\hline $\begin{array}{l}\text { Consumer Confidence In- } \\
\text { dicator }(\mathrm{CCI})\end{array}$ & $\begin{array}{l}\text { This index is built up by the European Com- } \\
\text { mission which conducts regular harmonized } \\
\text { surveys of consumers in each country. }\end{array}$ & $\begin{array}{l}\text { European } \\
\text { Commission } \\
\text { (DG ECFIN) }\end{array}$ \\
\hline Stock Returns (RET) & $\begin{array}{l}\text { Differences between logged stock indices prices } \\
\text { of the last and the first day of the quarter for } \\
\text { each country. }\end{array}$ & Datastream \\
\hline Rating (RAT) & $\begin{array}{l}\text { Credit rating scale built up from Fitch, } \\
\text { Moodys, S\&P ratings for each country. Fol- } \\
\text { lowing Blanco }(2001) \text {, we built up a quarterly } \\
\text { scale to estimate the effect of investor senti- } \\
\text { ment based on the rating offered by these three } \\
\text { rating agencies. }\end{array}$ & Bloomberg \\
\hline $\begin{array}{l}\text { Index of Fiscal Stance } \\
\text { (FSI) }\end{array}$ & $\begin{array}{l}\text { This indicator compares a target level of the } \\
\text { debt-GDP ratio at a given point in the fu- } \\
\text { ture with a forecast based on the government } \\
\text { budget constraint. It was built by Polito and } \\
\text { Wickens }(2011,2012) \text {. }\end{array}$ & $\begin{array}{l}\text { Provided by } \\
\text { the authors }\end{array}$ \\
\hline Stock Volatility (VOL) & $\begin{array}{l}\text { Quarterly average of monthly standard devia- } \\
\text { tion of the daily returns of each country's stock } \\
\text { market general index }\end{array}$ & Datastream \\
\hline $\begin{array}{l}\text { Index of Economic Policy } \\
\text { Uncertainty (EPU) }\end{array}$ & $\begin{array}{l}\text { This index draws on the frequency of news- } \\
\text { paper references to policy uncertainty; it was } \\
\text { built for Germany, France, Italy, Spain and } \\
\text { EMU by Baker et al. (2013). }\end{array}$ & www.policyuncert \\
\hline Variable & $\begin{array}{l}\text { Sectoral bank indices } \\
\text { Description }\end{array}$ & Source \\
\hline DSBANKS & DataStream Equity Index-Banks & DataStream \\
\hline DSFIN & DataStream Equity Index-Financial Services & DataStream \\
\hline
\end{tabular}

Table 4: Correlations between $a D t D$ s and national financial indicators

aDtD

Market sentiment indicators Sectoral bank indices

\begin{tabular}{lrrrrrr|rr}
\multicolumn{7}{c}{ Market sentiment indicators } & \multicolumn{2}{c}{ Sectoral bank indices } \\
& CCI & RET & RAT & FSI & VOL & EPU & DSBANKS & DSFIN \\
\hline AT & 0.87 & 0.08 & - & -0.55 & -0.86 & - & 0.70 & 0.49 \\
BE & 0.80 & -0.03 & -0.34 & -0.64 & -0.94 & - & 0.58 & 0.90 \\
DE & 0.71 & 0.40 & - & -0.83 & -0.92 & -0.51 & 0.44 & 0.53 \\
ES & 0.58 & -0.03 & 0.22 & -0.31 & -0.69 & -0.30 & 0.49 & 0.29 \\
FI & 0.53 & 0.05 & - & 0.17 & -0.88 & - & 0.31 & - \\
FR & 0.76 & 0.56 & -0.10 & -0.64 & -0.94 & -0.71 & 0.47 & 0.90 \\
GR & 0.79 & 0.67 & -0.60 & 0.65 & -0.88 & - & 0.81 & 0.41 \\
IE & 0.87 & 0.75 & -0.58 & 0.87 & -0.83 & - & 0.82 & 0.24 \\
IT & 0.68 & 0.53 & -0.61 & 0.04 & -0.92 & -0.64 & 0.60 & 0.66 \\
NL & 0.59 & 0.51 & - & 0.35 & -0.87 & - & 0.70 & 0.66 \\
PT & 0.24 & 0.06 & -0.34 & -0.36 & -0.95 & - & 0.21 & 0.23 \\
\hline
\end{tabular}


Table 5: Cross correlation of EMU-aDtDs with ECB indicators

\begin{tabular}{lr} 
Macroeconomic uncertainty indicators & EMU-aDtD \\
\hline ECBANY & -0.62 \\
ECBBAVE & -0.66 \\
ECBCHOU & -0.64 \\
ECBCBUS & -0.53 \\
ECBEAVE & -0.85 \\
ECBFPC & -0.85 \\
EUROINST & -0.94 \\
Banking risk indicator & EMU-aDtD \\
\hline ECBEDtD & 0.67 \\
\hline
\end{tabular}

Table 6: Granger causality between EMU-aDtDs and ECB indicators

\begin{tabular}{|c|c|c|c|}
\hline \multicolumn{4}{|c|}{ Macroeconomic uncertainty indicators } \\
\hline Null Hypothesis & F-Stats & Prob. & Significant at \\
\hline ECBANY does not Granger Cause EMU-aDTD & 2.29 & 0.12 & \\
\hline ECBBAVE does not Granger Cause EMU-aDTD & 0.28 & 0.76 & \\
\hline ECBCHOU does not Granger Cause EMU-aDTD & 1.97 & 0.16 & \\
\hline ECBCBUS does not Granger Cause EMU-aDTD & 1.39 & 0.27 & \\
\hline ECBEAVE does not Granger Cause EMU-aDTD & 0.40 & 0.67 & \\
\hline ECBFPC does not Granger Cause EMU-aDTD & 0.32 & 0.73 & \\
\hline EUROINST does not Granger Cause EMU-aDTD & 6.18 & 0.04 & $5 \%$ \\
\hline \multicolumn{4}{|c|}{ Banking risk indicators } \\
\hline Null Hypothesis & F-Stats & Prob. & Significant at \\
\hline ECBDtD does not Granger Cause EMU-aDtD & 0.12 & 0.89 & \\
\hline \multicolumn{4}{|c|}{ Macroeconomic uncertainty indicators } \\
\hline Null Hypothesis & F-Stats & Prob. & Significant at \\
\hline EMU-aDtD does not Granger Cause ECBANY & 5.08 & 0.01 & $5 \%$ \\
\hline EMU-aDtD does not Granger Cause ECBBAVE & 8.76 & 0.00 & $1 \%$ \\
\hline EMU-aDtD does not Granger Cause ECBCHOU & 0.64 & 0.53 & \\
\hline EMU-aDtD does not Granger Cause ECBCBUS & 4.00 & 0.03 & $5 \%$ \\
\hline EMU-aDtD does not Granger Cause ECBEAVE & 2.93 & 0.07 & $10 \%$ \\
\hline EMU-aDtD does not Granger Cause ECBFPC & 7.51 & 0.00 & $1 \%$ \\
\hline EMU-aDtD does not Granger Cause EUROINST & 4.09 & 0.01 & $5 \%$ \\
\hline \multicolumn{4}{|c|}{ Banking risk indicators } \\
\hline Null Hypothesis & F-Stats & Prob. & Significant at \\
\hline EMU-aDtD does not Granger Cause ECBDtD & 6.53 & 0.0047 & $1 \%$ \\
\hline
\end{tabular}


Table 7: Correlations among aggregate DtD indices

\begin{tabular}{rrcccccccccc} 
& AT & BE & ES & DE & FI & FR & GR & IE & IT & NL & PT \\
\hline BE & 0.83 & & & & & & & & & & \\
ES & 0.70 & 0.83 & & & & & & & & & \\
DE & 0.79 & 0.66 & 0.65 & & & & & & & & \\
FI & 0.71 & 0.63 & 0.66 & 0.78 & & & & & & & \\
FR & 0.88 & 0.83 & 0.67 & 0.75 & 0.62 & & & & & & \\
GR & 0.74 & 0.89 & 0.72 & 0.51 & 0.53 & 0.69 & & & & & \\
IE & 0.78 & 0.93 & 0.86 & 0.62 & 0.63 & 0.74 & 0.84 & & & & \\
IT & 0.84 & 0.84 & 0.75 & 0.81 & 0.74 & 0.76 & 0.81 & 0.78 & & & \\
NL & 0.79 & 0.79 & 0.65 & 0.69 & 0.65 & 0.72 & 0.78 & 0.71 & 0.80 & & \\
PT & 0.77 & 0.84 & 0.73 & 0.58 & 0.58 & 0.70 & 0.88 & 0.77 & 0.84 & 0.67 & \\
EMU & 0.91 & 0.95 & 0.87 & 0.80 & 0.77 & 0.86 & 0.88 & 0.92 & 0.93 & 0.85 & 0.88 \\
\hline
\end{tabular}

Table 8: Schematic connectedness table

\begin{tabular}{cccccc} 
& $x_{1}$ & $x_{2}$ & $\ldots$ & $x_{N}$ & From others \\
\hline$x_{1}$ & $d_{11}^{H}$ & $d_{12}^{H}$ & $\ldots$ & $d_{1 N}^{H}$ & $\sum j=1^{N} d_{1 j}^{H}, j \neq 1$ \\
$x_{2}$ & $d_{21}^{H}$ & $d_{22}^{H}$ & $\ldots$ & $d_{2 N}^{H}$ & $\sum j=1^{N} d_{2 j}^{H}, j \neq 2$ \\
.. &.. & $\ldots$ &.. &.. & \\
.. &.. & $\ldots$ &.. &.. & \\
$x_{N}$ & $d_{N 1}^{H}$ & $d_{N 2}^{H}$ & $\ldots$ & $d_{N N}^{H}$ & $\sum j=1^{N} d_{N j}^{H}, j \neq N$ \\
\hline To others & $\sum i=1^{N} d_{i 1}^{H}$ & $\sum i=1^{N} d_{i 2}^{H}$ & & $\sum i=1^{N} d_{i N}^{H}$ & $\frac{1}{N} \sum i, j=1^{N} d_{i N}^{H}$ \\
& $i \neq 1$ & $i \neq 2$ & $\ldots$ & $i \neq N$ & $i \neq N$ \\
\hline
\end{tabular}




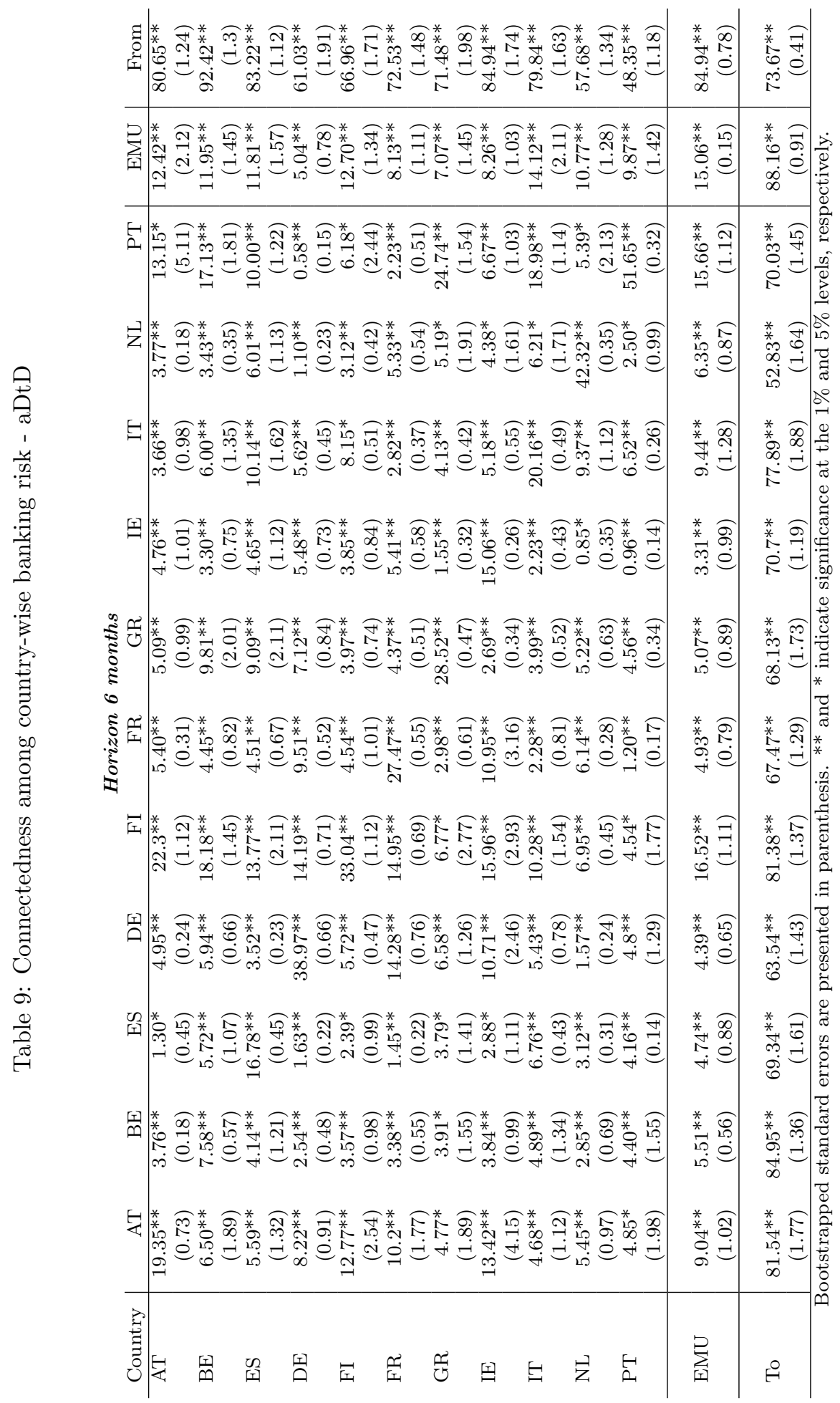




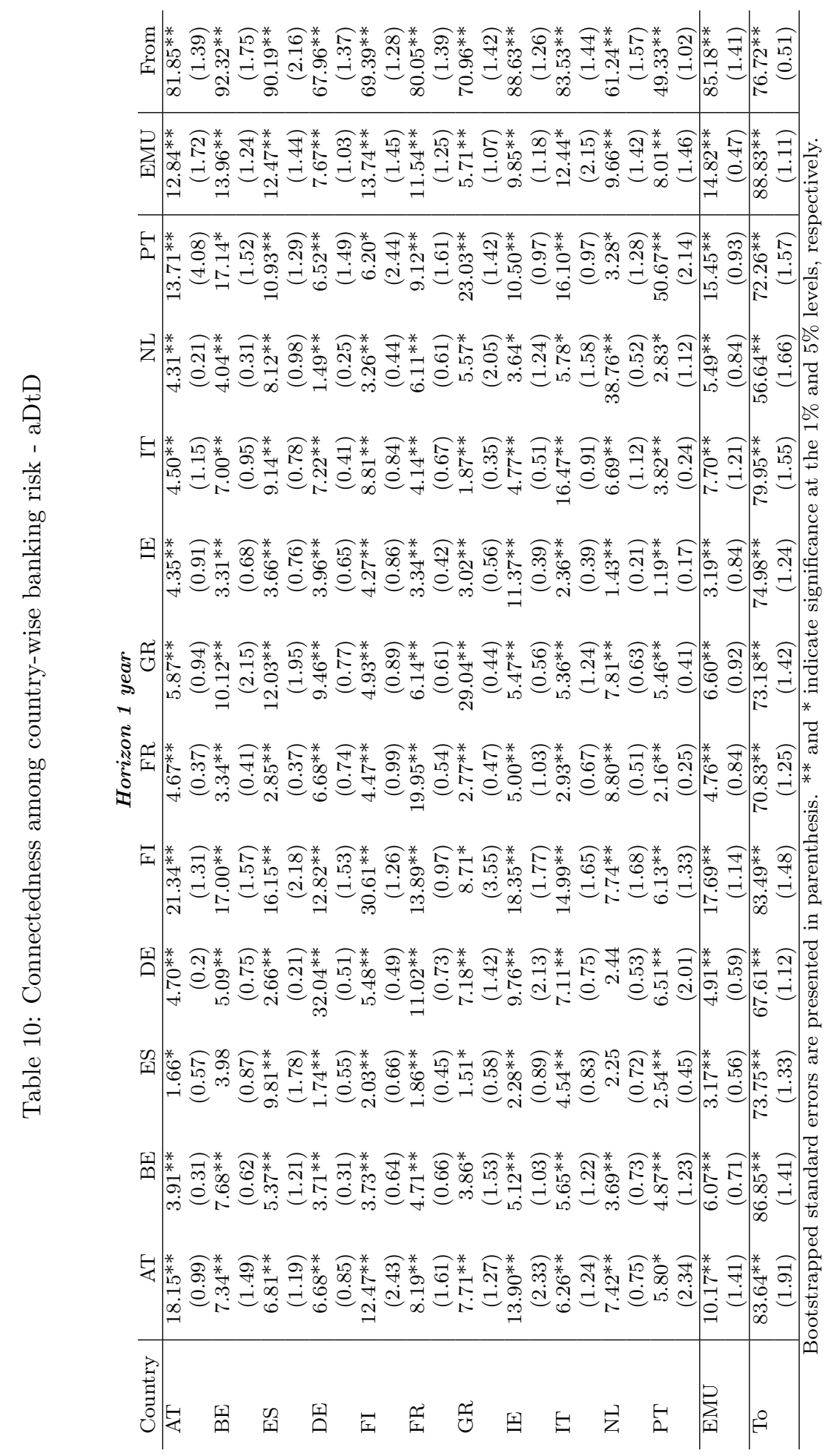


Figure 1: Size distribution of banks in each EMU country
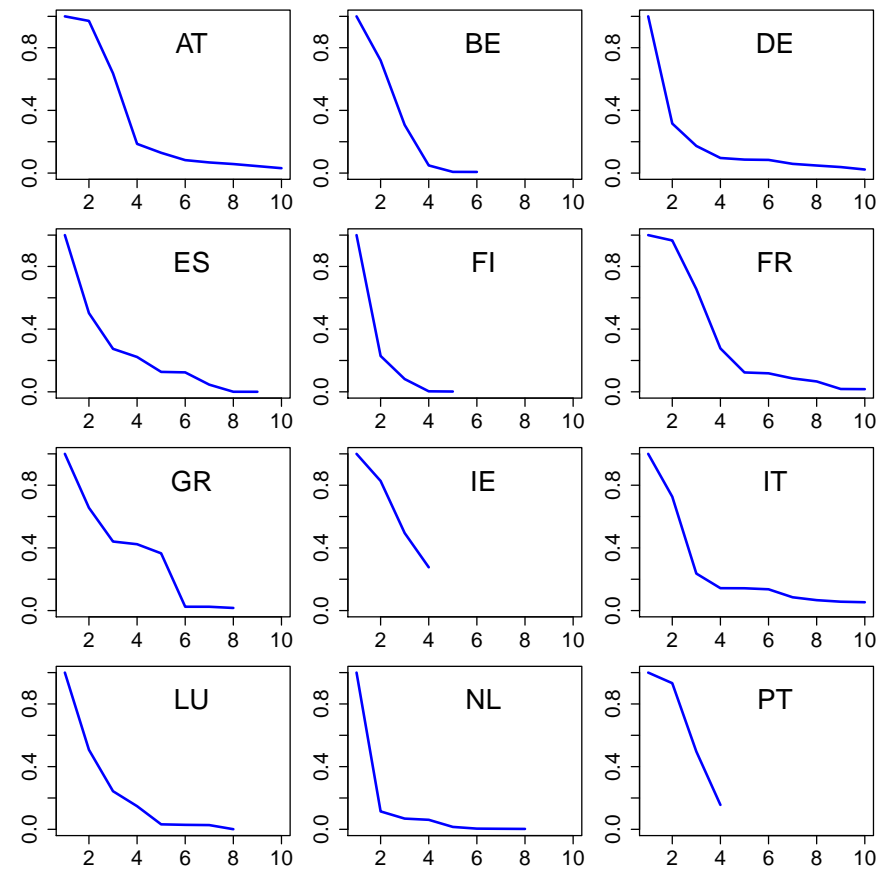

AT: Austria, BE: Belgium, ES: Spain, DE: Germany, FI: Finland, FR: France, GR: Greece, IE: Ireland, IT: Italy, NL: The Netherlands, PT: Portugal, EMU: European Economic and Monetary Union. We show the relative size of banking firms (by total assets in 2010) for each EMU country under study, being the total asset of the biggest bank in a particular country normalized to one. Source: Bankscope. 
Figure 2: Economic dependence and home bias
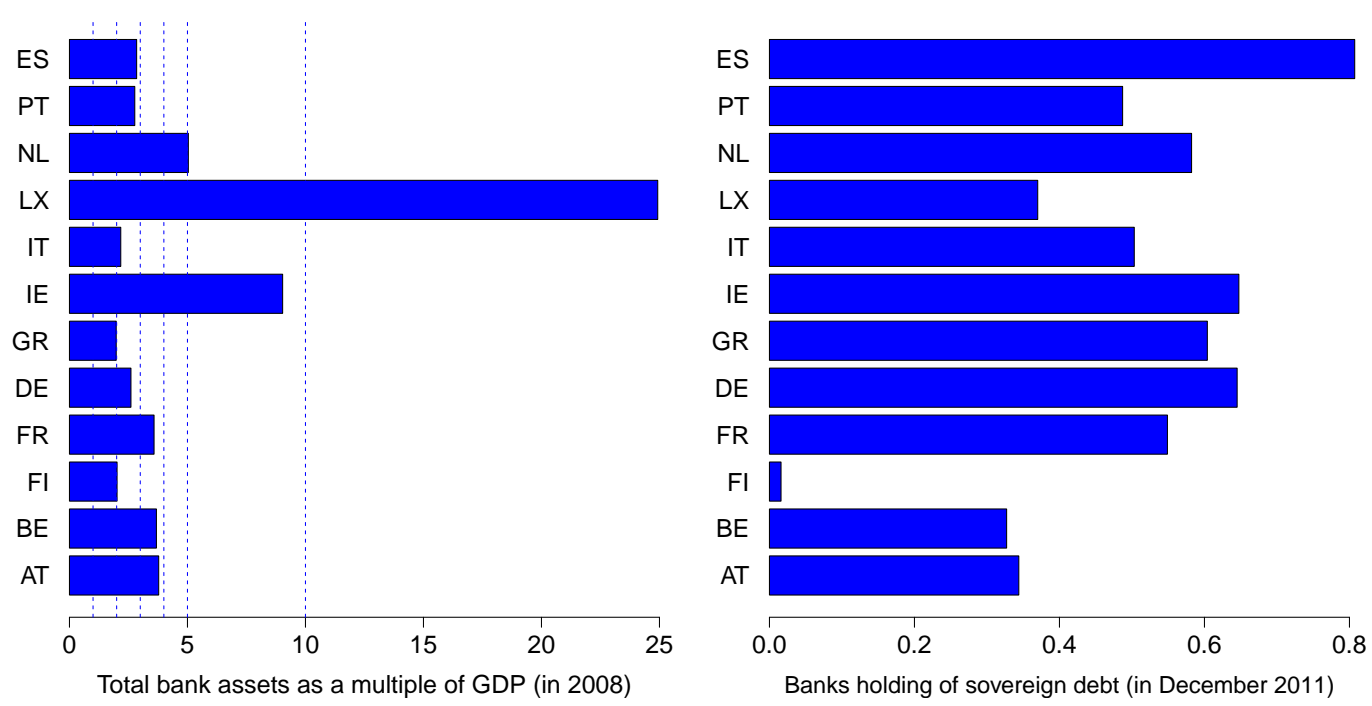

(a) MFI total assets as multiple of GDP

(b) Banks' holding of its own sovereign bonds (as \% of total notional outstanding)

MFI: Monetary Financial Institution as classified by Organization for International Co-operation and Development (OECD). Datasource: OECD, National Central Banks, European Bank Authority stress test 2011 and Eurostat. 
Figure 3: ISO-DtD curves

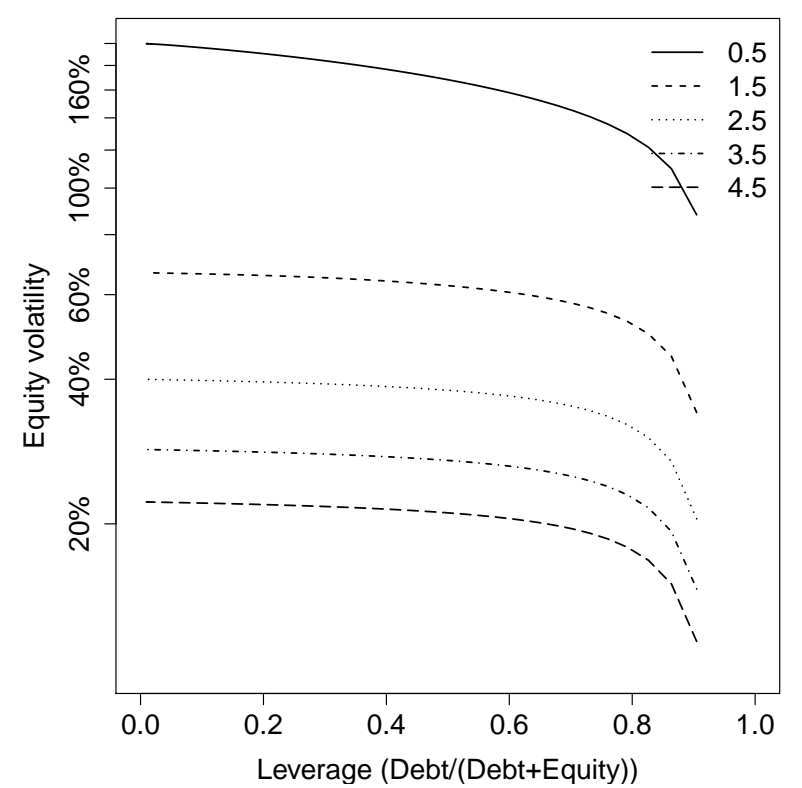

The lines represent different values of $D t D$ for varying combinations of leverage and equity volatility.

Figure 4: No of banks used every period for each country

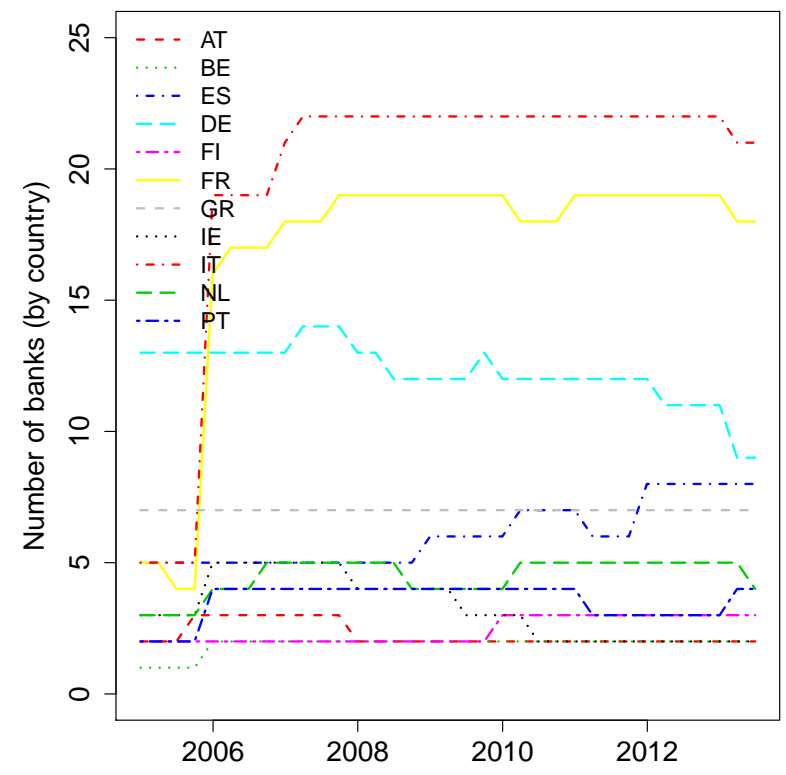


Figure 5: Country level $a D t D$

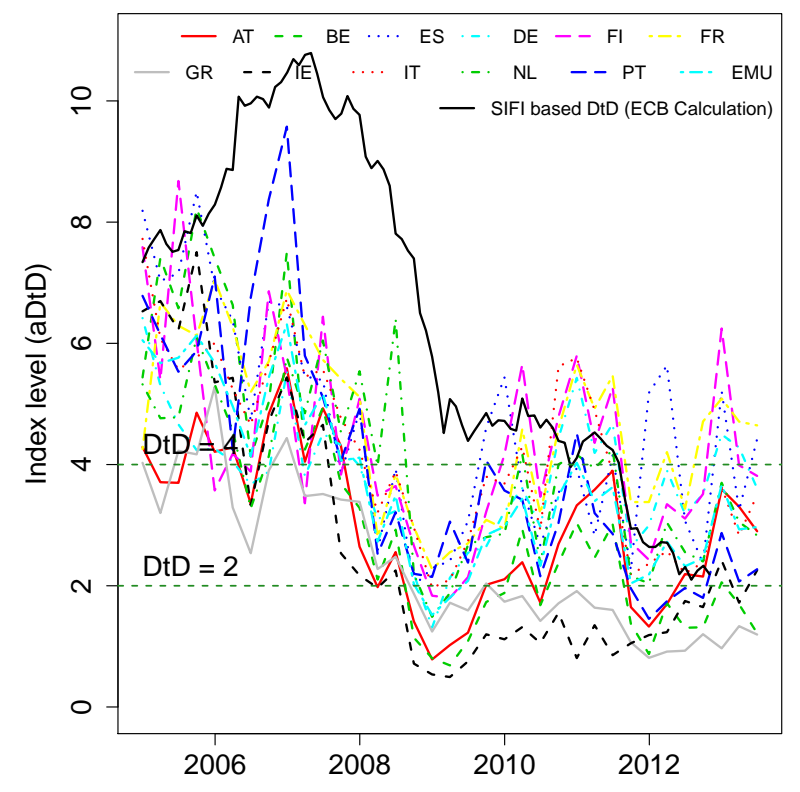


Figure 6: Country-wise indices

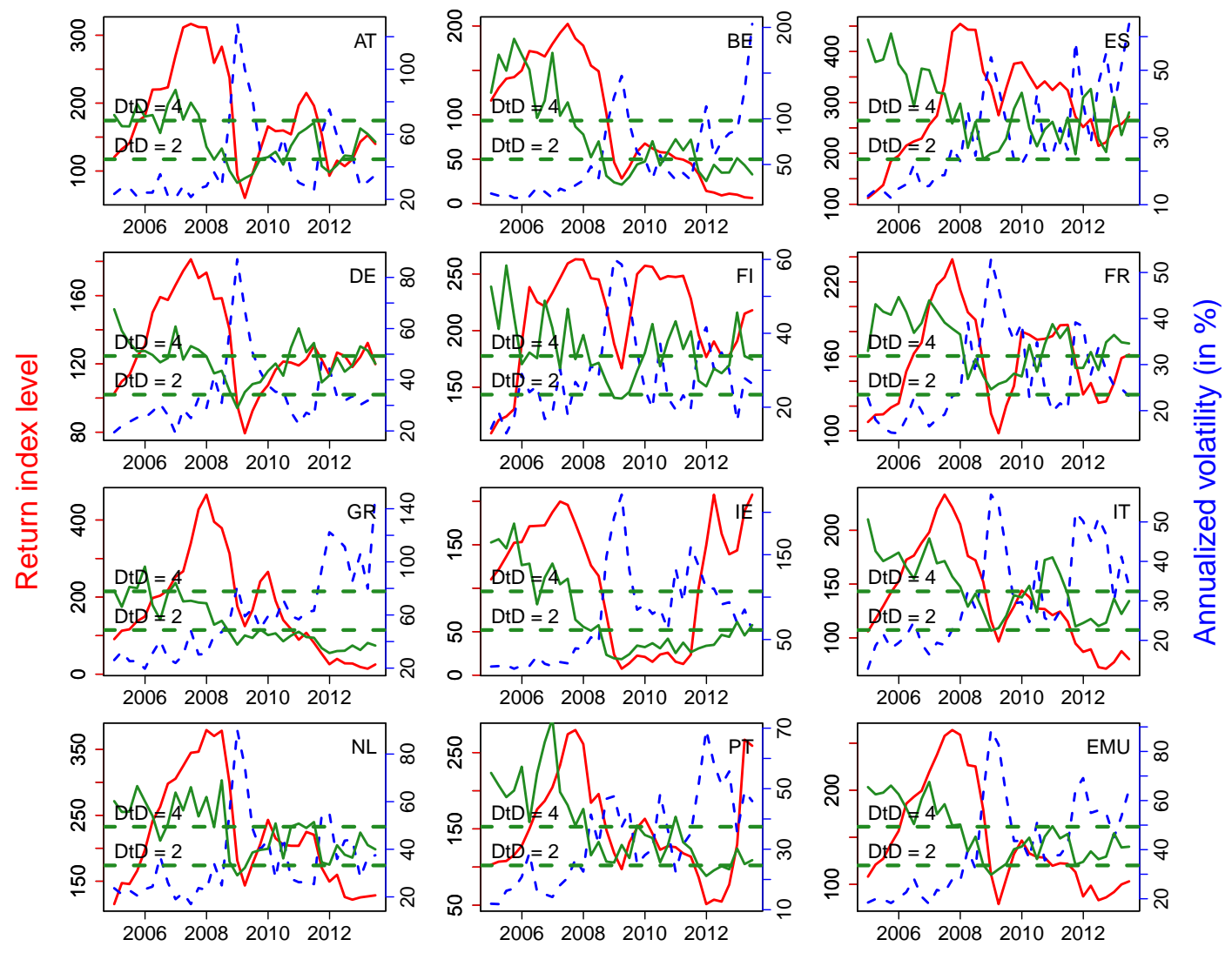

The blue, green and red line represent volatility, $a D t D$ and equity index level respectively. 
Figure 7: Equity index and aDtD during the crisis
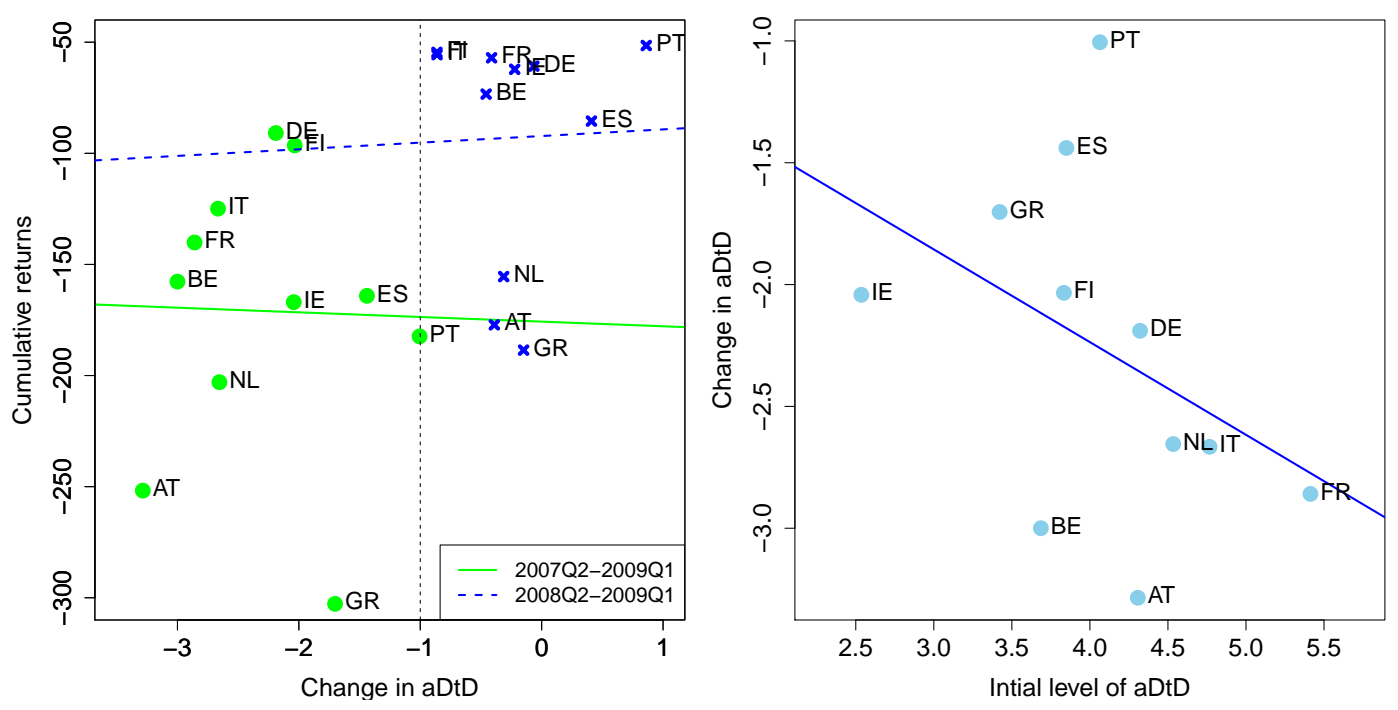

(a) Cumulative returns vs DtD

(b) Scatter plot with trend line (2007-Q2 to 2009-Q1) 
Figure 8: Linkages based on Granger causality tests

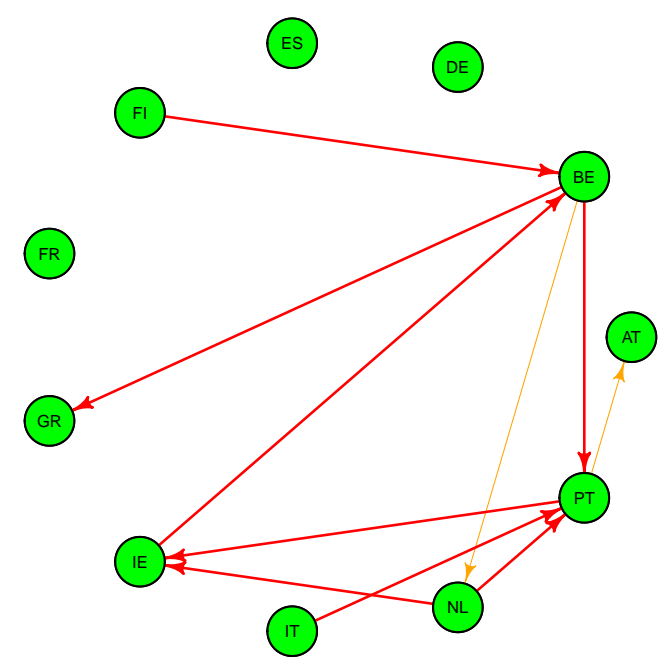

We show the most important directional causalities among the pairs of 12 countries' aDtDs. Red and orange lines represent significance at $10 \%$ and $5 \%$ level respectively.

Figure 9: Net directional connectedness among aDtDs

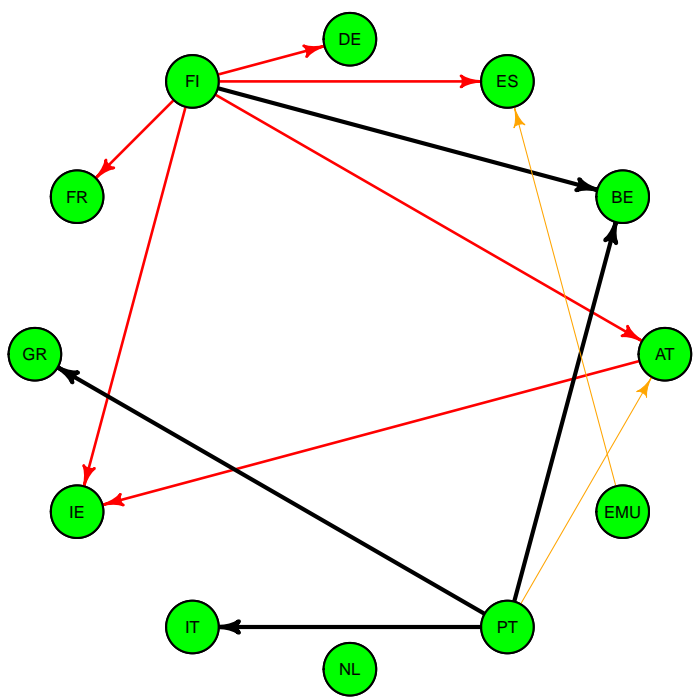

(a) Based on 6 months horizon

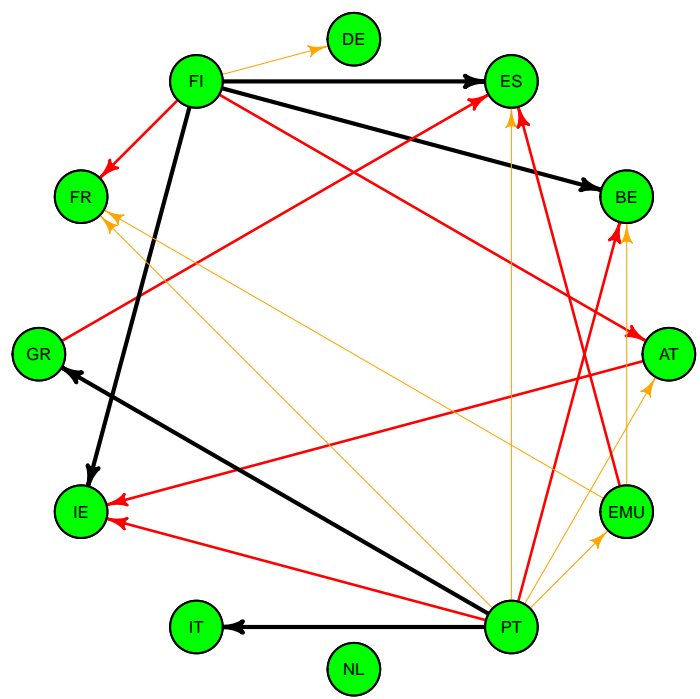

(b) Based on 1 year horizon

We show the most important directional connections among the pairs of 12 countries' aDtDs. Black, red and orange lines represent the first, second and third deciles based on net pairwise directional connectedness derived from Tables 9 and 10. 